\title{
Clinical Utility of Combined Circulating Tumor Cell and Circulating Tumor DNA Assays for Diagnosis of Primary Lung Cancer
}

\author{
SEONG MI MOON ${ }^{1,2}, \mathrm{JI}^{-H O} \mathrm{KIM}^{3}$, SEONG KEUN KIM ${ }^{4}$, SEONWOO KIM ${ }^{5}$, HYUK-JUNG KWON ${ }^{3}$, \\ JIN-SIK BAE ${ }^{3}$, SUNGHOON LEE ${ }^{3}$, HYE SEON LEE ${ }^{4}$, MI-YOUNG CHOI ${ }^{4}$, BYUNG HEE JEON ${ }^{4}$, \\ BYEONG-HO JEONG ${ }^{1}$, KYUNGJONG LEE ${ }^{1}$, HONG KWAN KIM ${ }^{6}$, JHINGOOK KIM $^{6}$ and SANG-WON UM ${ }^{1}$ \\ ${ }^{1}$ Division of Pulmonary and Critical Care Medicine, Department of Medicine, \\ Samsung Medical Center, Sungkyunkwan University School of Medicine, Seoul, Republic of Korea; \\ ${ }^{2}$ Division of Pulmonary and Critical Care Medicine, Department of Medicine, \\ Samsung Changwon Hospital, Sungkyunkwan University School of Medicine, Changwon, Republic of Korea; \\ ${ }^{3}$ EDGC, Inc., Incheon, Republic of Korea; \\ ${ }^{4}$ CytoGen Inc., Seoul, Republic of Korea; \\ ${ }^{5}$ Statistics and Data Center, Samsung Medical Center, Seoul, Republic of Korea; \\ ${ }^{6}$ Department of Thoracic and Cardiovascular Surgery, Samsung Medical Center, \\ Sungkyunkwan University School of Medicine, Seoul, Republic of Korea
}

\begin{abstract}
Background/Aim: Although it has been suggested that circulating tumor cells (CTCS) and circulating tumor DNA (ctDNA) might be used in a complementary manner in lung cancer diagnosis, limited confirmatory data are available. In this prospective study, we evaluated the diagnostic performance of each assay separately and in combination. Patients and Methods: From March 2018 to January 2019, patients with suspected primary lung cancer, who underwent routine lung cancer work-up and peripheral blood sampling, were prospectively enrolled in the study. Epithelial cell adhesion molecule and cytokeratin served as markers of CTCs. In terms of ctDNA analysis, single-nucleotide variants were evaluated via next-generation sequencing. Results: We analyzed 111 patients, including 99 with primary lung cancer and 12 with benign pulmonary disease. The median number of CTCs in $10 \mathrm{ml}$ of blood was 3. The most frequently detected single nucleotide variants of ctDNA were TP53, CDKN2A, and
\end{abstract}

This article is freely accessible online.

Correspondence to: Sang-Won Um MD, MPH, Ph.D., Division of Pulmonary and Critical Care Medicine, Department of Medicine, Samsung Medical Center, Sungkyunkwan University School of Medicine, Irwon-ro 81, Gangnam-gu, Seoul 06351, Republic of Korea. Tel: +82 234101645, Fax: +82 234106956, e-mail: sangwonum@skku.edu

Key Words: Liquid biopsy, circulating tumor cell, circulating tumor DNA, primary lung cancer, diagnosis.
EGFR. The diagnostic sensitivity of conventional tumor marker (combination of carcinoembryonic antigen/CYFRA 21$1 /$ neuron-specific enolase) was $66.7 \%$, while those of the ctDNA and CTC assays were $72.7 \%$ and $65.7 \%$, respectively. The sensitivity of the CTC/ctDNA combination (95.0\%) was significantly greater than those of the CTC $(p<0.001)$, ctDNA $(p<0.001)$, or conventional tumor marker $(p<0.001)$ alone. Subgroup analysis revealed that the sensitivity of the combination assay was greater than those of the CTC or ctDNA assays alone, regardless of tumor stage or histopathology type. Conclusion: The CTC/ctDNA combination assay enhanced the sensitivity of primary lung cancer diagnosis. The combination assay strategy may be clinically useful and could enhance the early detection of lung cancer (ClinicalTrials.gov number: NCT03479099).

Lung cancer is the leading cause of cancer-related death (1, 2 ). To reduce the burden of this disease, key strategies include prevention, new treatments, and early detection (1, 3 ). Recently, liquid biopsy has been introduced into clinical practice; it exhibits great potential in terms of early diagnosis, prognosis evaluation, treatment response monitoring, prediction of resistance to therapy and detection of residual disease in a non-invasive manner (4-9).

Of the various circulating biomarkers available for liquid biopsy, circulating tumor cells (CTC) and circulating tumor DNA (ctDNA) from peripheral blood are major candidate markers $(3,4,10,11)$. CTCs are viable cells from primary tumors that spread via blood or lymphatic vessels; they 
provide information regarding tumor morphology and protein expression $(3,8)$. In terms of lung cancer diagnosis, the reported diagnostic sensitivity of CTCs ranges from 18 to $100 \%$ (3). ctDNAs are small double-stranded DNA fragments in plasma, and their release into the bloodstream reflects active secretion from tumor cells, as well as apoptosis, and necrosis; ctDNAs can be used to detect somatic mutations of the primary tumor $(8,12)$. The reported sensitivity of ctDNA analysis for lung cancer diagnosis ranges from 17 to $100 \%$ (3). Because the two technologies exhibit unique strengths and limitations in terms of lung cancer diagnosis $(3,10)$, it has been suggested that they could be used in a complementary manner as cancer biomarkers $(3,13)$. However, there are limited data regarding the use of CTC/ctDNA combination in the diagnosis of primary lung cancer.

Thus, the aim of this prospective study was to evaluate the clinical utility of combined CTC and ctDNA assay in the diagnosis of primary lung cancer. The diagnostic performances of each assay, both separately and in combination, were assessed and compared to the diagnostic performances achieved using conventional tumor markers.

\section{Patients and Methods}

Study design and patients. The primary objective of this prospective observational study was to compare the sensitivity of a combined CTC/ctDNA assay to the sensitivities of CTC and ctDNA assays alone, in terms of primary lung cancer diagnosis. The secondary objectives of the study were to compare accuracies, specificities, predictive values, and false diagnosis rates among the assays. Assays of conventional tumor markers, including carcinoembryonic antigen (CEA), CYFRA 21-1, and neuron-specific enolase (NSE), were compared to the combined CTC/ctDNA assay.

From March 2018 to January 2019, patients who visited the outpatient clinic of the Samsung Medical Center (a 1,979-bed referral hospital in Seoul, Republic of Korea) for evaluation and management of suspected primary lung cancer were screened for inclusion in the study. Patients between 18 and 80 years of age without any history of malignancy within the prior 5 years, who agreed to participate, were enrolled in the study. Patients with a previous history of lung cancer were excluded. After routine workup, patients diagnosed with tumors other than lung cancer or multiple primary lung cancers, as well as those with inconclusive diagnoses because of incomplete work-up, were excluded. Regarding cancer staging, pathological staging was determined patients who underwent surgery and clinical staging for patients that did not undergo surgery.

This study protocol was reviewed and approved by the Institutional Review Board of the Samsung Medical Center (IRB No. 2018-01-081-008). Written informed consent was obtained from each patient before enrollment. This trial was registered at ClinicalTrials.gov (registration number: NCT 03479099).

Specimen collection, delivery, and processing. After obtaining consent from the patients, routine lung cancer work-up and peripheral blood sampling (liquid biopsy) were performed. Twenty $\mathrm{ml}$ of fresh blood were collected from each patient; samples were delivered to CytoGen Inc. (Seoul, Republic of Korea) for centrifugation and CTC extraction, while the separated plasma was delivered to EDGC (Incheon, Republic of Korea) for detection of ctDNA.

CTC extraction and analysis. Blood samples were processed using CytoGen liquid biopsy platform (14). CTCs were enriched using a CTC isolation kit (CytoGen Inc.) and a Smart Biopsy Cell Isolator (CytoGen Inc.). The presence of CTCs was verified by multiimmunofluorescence staining. The nucleic acid dye 4'6-diamidino-2phenylindole (DAPI) was used to label the nuclei positive cells and CD45 was used to identify leukocytes. CTCs were defined as cells positive for DAPI, epithelial cell adhesion molecule (EpCAM) and/or cytokeratin (CK), but negative for CD45 (Figure 1). CTC images were captured by Smart Biopsy Cell Image Analyzer (CytoGen Inc.) and CTC number was counted by the supporting software.

ctDNA extraction, sequencing, and analysis. From the isolated plasma, ctDNA was extracted using chemagic cfDNA 5k kit special H24 (PerkinElmer, Waltham, MA, USA) and the automated nucleic acid purification instrument, Chemagic 360 (PerkinElmer), in accordance with manufacturer's instructions. Somatic alterations of cancer-related genes were detected via paired-end sequencing with 150 base pair reads using NextSeq 500/550 High-Output v2 kit (300 cycles) and Nextseq 500 platform (Illumina, San Diego, CA, USA). The targeted libraries were prepared using an EDGC 54gene targeted panel (Table I). The mean sequencing depth was $3,000 \times$ and significantly elevated single nucleotide variants (SNVs) from the Catalogue of Somatic Mutations in Cancer database were identified.

Definition of primary lung cancer. The final diagnosis was made based on tissue histopathology obtained during work-up. The cutoff values of conventional tumor markers were $\leq 7 \mathrm{ng} / \mathrm{ml}$ for CEA, $\leq 3.3 \mathrm{ng} / \mathrm{ml}$ for CYFRA $21-1$, and $\leq 12 \mathrm{ng} / \mathrm{ml}$ for NSE, according to our laboratory reference limits and previous studies (15-18); elevated levels were considered to be predictive of lung cancer. CTC counts $\geq 2$ in $10 \mathrm{ml}$ of peripheral blood were considered to be predictive of lung cancer, as was the presence of SNVs in ctDNA. Various CTC cut-off values were tested and $>2$ cells positive for at least one marker (EpCAM or CK) showed the best diagnostic performance compared to other combinations (data not shown). Patients for whom ctDNA data were missing were considered to be false negatives for analysis purposes. In analysis of combination assays, the elevated level of at least one assay was considered to be predictive of lung cancer.

Statistical analyses. A sample size of 99 lung cancer patients achieves $80 \%$ power to detect $10 \%$ difference in the diagnostic sensitivity of the combined CTC/ctDNA assay (compared to the sensitivities of the CTC and ctNDA assays alone) using McNemar's test with a significance level of 0.025 for each comparison. The power was computed using binomial enumeration of all possible outcomes and the proportion of discordant pairs was assumed to be 0.11 .

Categorical variables are presented as numbers (percentages) and continuous variables as medians [interquartile range (IQR)]. Sensitivities, accuracies and specificities were calculated based on assay data and final diagnoses. We derived positive and negative predictive values as well as false positive and false negative rates for diagnosis. Comparisons of the sensitivities, accuracies, 

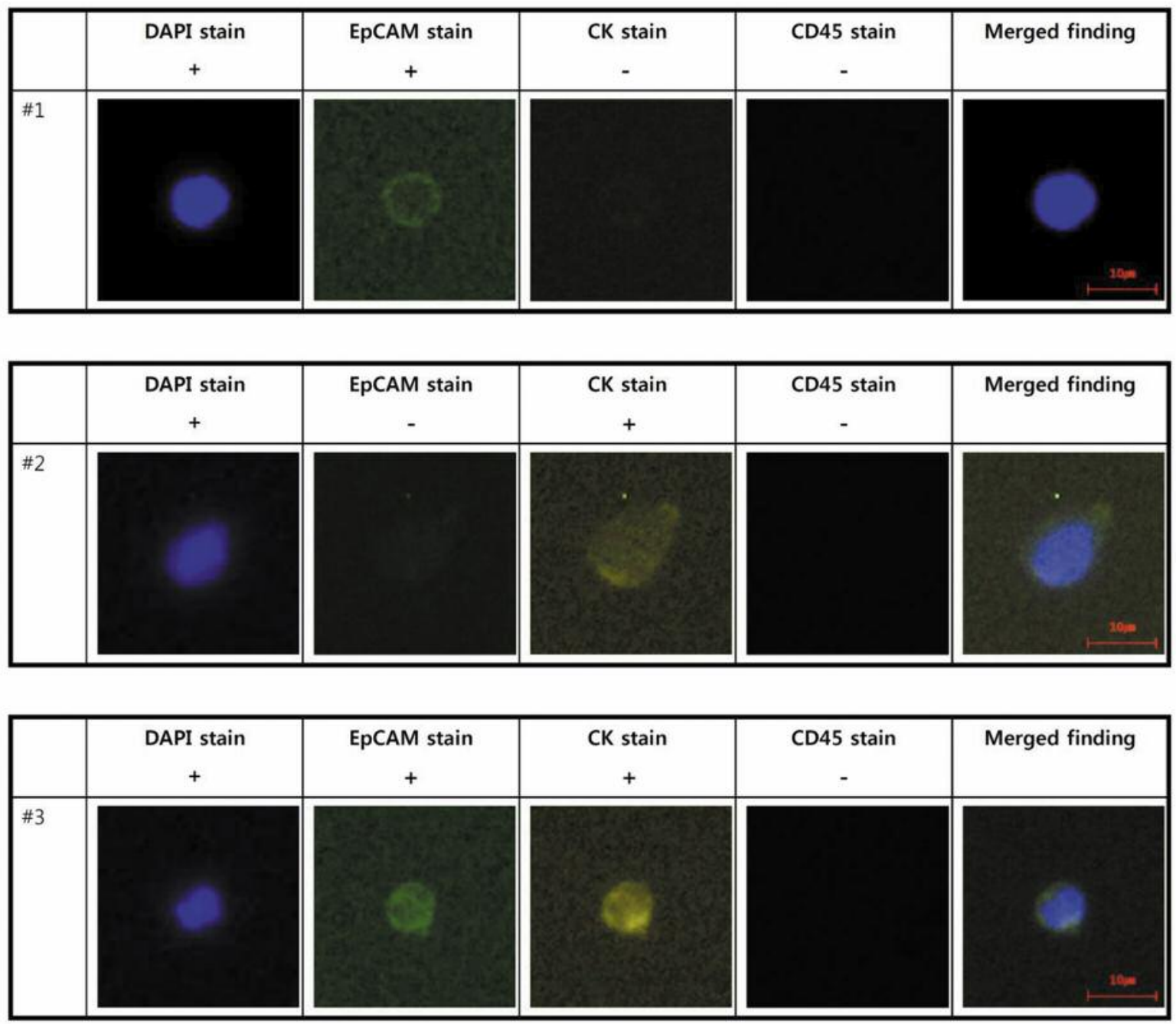

Figure 1. Representative circulating tumor cell (CTC) analyses. CTCs were defined as cells positive for 4'6-diamidino-2-phenylindole (DAPI), epithelial cell adhesion molecule (EPCAM), and/or cytokeratin (CK), but negative for CD45. Here, three CTCs were analyzed (one EpCAM ${ }^{+} / C K^{-}$, one $\mathrm{EpCAM}^{-} / \mathrm{CK}^{+}$, and one $\left.\mathrm{EpCAM} \mathrm{M}^{+} / \mathrm{CK}^{+}\right)$.

Table I. Panel of 54 target genes for characterization of single nucleotide variants in circulating tumor DNA.

\begin{tabular}{|c|c|c|c|c|c|c|c|c|c|}
\hline AKT1 & ALK & APC & AR & ARID1A & BRAF & BRCA1 & BRCA2 & CDKN2A & CREBBP \\
\hline CTNNB1 & DDR2 & EGFR & ERBB2 & ESR1 & FBXW7 & FGFR1 & FGFR3 & FLT3 & FOXL2 \\
\hline GNA11 & GNAQ & GNAS & HRAS & IDH1 & IDH2 & JAK2 & KEAP1 & KIT & KMT2D \\
\hline KRAS & MAP2K1 & MAP2K2 & MED12 & MEN1 & MET & MTOR & MYC & MYCN & MYD88 \\
\hline NFE2L2 & NRAS & NTRK1 & NTRK3 & PBRM1 & PDGFRA & PIK3CA & PTEN & RET & ROS1 \\
\hline SMAD4 & TERT & TGFBR2 & TP53 & & & & & & \\
\hline
\end{tabular}

specificities, false positive and false negative rates were performed using the exact binomial test with a significance level of 0.025 . The comparison of positive and negative predictive values of assays were performed using the generalized score statistic for paired data. All statistical analyses were performed using SPSS ver. 22 software (IBM Corp., New York, NY, USA) and R 3.4.4 (R Development Core Team, Vienna, Austria; www.R-project.org).

\section{Results}

Study population and baseline characteristics. We screened 230 patients with suspected primary lung cancer. One patient older than 80 years, 94 who refused to participate, and 8 with histories of other cancers within the prior 5 years were 
Patients with suspected lung cancer between March 2018 and January 2019 were screened $(n=230)$.

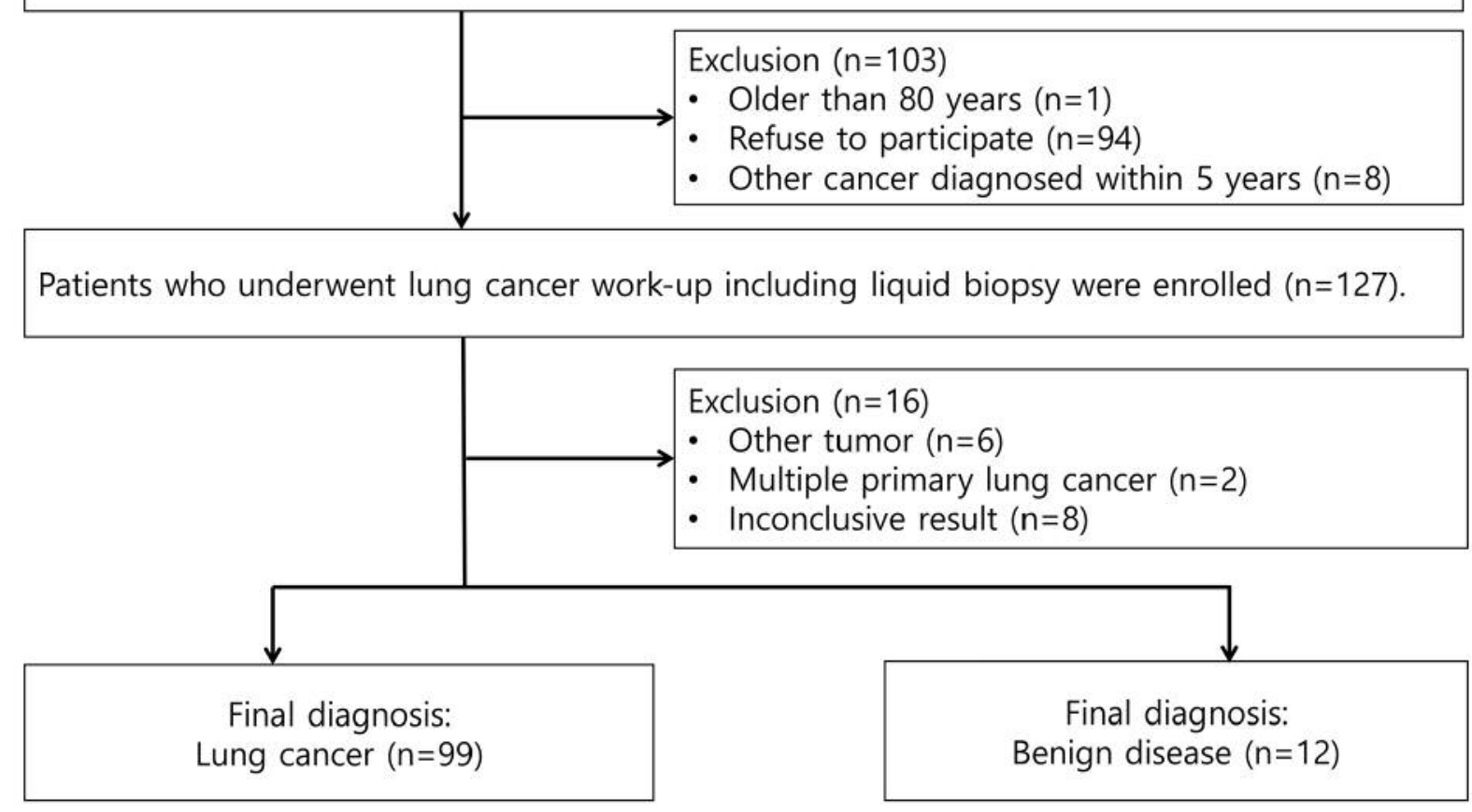

Figure 2. Flowchart of patient selection.

excluded. A total of 127 patients were enrolled and underwent diagnostic work-up for lung cancer and blood sampling for the liquid biopsy. Six were diagnosed with malignancies other than primary lung cancer [lymphoma $(n=2)$, thymoma $(n=2)$, atypical carcinoid $(n=1)$ and solitary fibrous tumor of the pleura $(n=1)] ; 2$ were diagnosed with synchronous multiple primary lung cancers; and 8 for whom data were inconclusive (because of incomplete work-up) were also excluded. Finally, 99 patients with primary lung cancer and 12 with benign pulmonary disease were analyzed (Figure 2). Their baseline characteristics are listed in Table II. The median age was 64 years (IQR=57-69 years); 78 (70\%) were men. The initially suspected cancer stages were I and II in 39 patients (35\%) and III and IV in 72 patients (65\%). Following work-up for diagnosis, 99 patients had lung cancer and 12 patients had benign pulmonary disease, including pulmonary aspergillosis $(\mathrm{n}=2)$, pulmonary tuberculosis $(\mathrm{n}=3)$, non-specific inflammation $(n=6)$ and sarcoidosis $(n=1)$ were identified. The final clinical or pathological stages of lung cancer patients $(n=99)$ were stage I-II NSCLC for $33(33 \%)$ patients, stage III-IV NSCLC for $59(60 \%)$ patienst, limited disease of SCLC for $1(1 \%)$ patient and extensive disease of SCLC for $6(6 \%)$ patients. In terms of histopathology, $55 \%$ of patients $(62 / 99)$ had adenocarcinomas and $22 \%$ of patients (24/99) had squamous cell carcinomas. The most common comorbidity was hypertension $(\mathrm{n}=38,34 \%)$, followed by diabetes mellitus $(\mathrm{n}=23,21 \%)$ and chronic obstructive pulmonary disease $(\mathrm{n}=14,13 \%)$.

Diagnostic performance of liquid biopsy assay. Table III lists the diagnostic performances of the tumor marker and liquid biopsy assays. The diagnostic sensitivity of tumor marker (combination of CEA/CYFRA 21-1/NSE) was 66.7\%, while the sensitivities of the ctDNA and CTC assays were $72.7 \%$ and $65.7 \%$, respectively. The sensitivity of the combination CTC/ctDNA assay (95.0\%) was significantly greater than the sensitivities of the CTC $(p<0.001)$, ctDNA $(p<0.001)$ or tumor marker $(p<0.001)$ assays alone. Of the three different combinations of the two assays, the combined CTC/ctDNA assay achieved a sensitivity (95.0\%) similar to the sensitivities of a combination tumor marker/ctDNA assay $(88.9 \% ; p=0.292)$ and a tumor marker/CTC assay $(89.9 \%$; $p=0.454)$. The sensitivity of the tumor marker/CTC/ctDNA combination assay was similar $(98.0 \%)$ to that of the CTC/ctDNA combination assay $(95.0 \% ; p=0.250)$.

The tumor marker $(67.6 \%)$, CTC $(63.1 \%)$, and ctDNA $(69.4 \%)$ assays achieved similar diagnostic accuracies; the accuracy of the combination CTC/ctDNA assay was significantly greater $(86.5 \%)$ than the accuracies of the CTC $(p<0.001)$ or ctDNA $(p<0.001)$ assays alone. The accuracy of 
Table II. Characteristics of the study population $(n=111)$.

\begin{tabular}{|c|c|}
\hline & Total $(n=111)$ \\
\hline Age, years & $64(57-69)$ \\
\hline Male & $78(70)$ \\
\hline \multicolumn{2}{|l|}{ Smoking status } \\
\hline Never-smoker & $39(35)$ \\
\hline Smoker & $72(65)$ \\
\hline Smoking amount, pack-years & $40(20-50)$ \\
\hline \multicolumn{2}{|l|}{ Initial suspected stage at the time of enrollment } \\
\hline I & $24(22)$ \\
\hline II & $15(13)$ \\
\hline III & $33(30)$ \\
\hline IV & $39(35)$ \\
\hline \multicolumn{2}{|l|}{ Final diagnosis } \\
\hline Benign pulmonary disease* & $12(11)$ \\
\hline Lung cancer & $99(89)$ \\
\hline \multicolumn{2}{|l|}{ Histopathology } \\
\hline Adenocarcinoma & $62(55)$ \\
\hline Squamous cell carcinoma & $24(22)$ \\
\hline Large cell neuroendocrine carcinoma & $1(1)$ \\
\hline Poorly differentiated non-small cell carcinoma & $5(5)$ \\
\hline Small cell lung cancer & $7(6)$ \\
\hline \multicolumn{2}{|l|}{$\begin{array}{l}\text { Clinical or pathological stage of } \\
\text { lung cancer patients }(n=99)\end{array}$} \\
\hline IA1 & $1(1)$ \\
\hline IA2 & $8(8)$ \\
\hline IA3 & $6(6)$ \\
\hline IB & $6(6)$ \\
\hline IIA & $4(4)$ \\
\hline IIB & $8(8)$ \\
\hline IIIA & $21(21)$ \\
\hline IIIB & $5(5)$ \\
\hline IIIC & $3(3)$ \\
\hline IVA & $12(12)$ \\
\hline IVB & $18(18)$ \\
\hline Limited disease of small cell lung cancer & $1(1)$ \\
\hline Extensive disease of small cell lung cancer & $6(6)$ \\
\hline EGFR mutations detected in 99 lung cancer tissues & $36(36)$ \\
\hline \multicolumn{2}{|l|}{ Comorbidities } \\
\hline Hypertension & $38(34)$ \\
\hline Diabetes mellitus & $23(21)$ \\
\hline Chronic obstructive pulmonary disease & $14(13)$ \\
\hline Previous tuberculosis infection & $12(11)$ \\
\hline Ischemic heart disease & $9(8)$ \\
\hline Stroke & $5(5)$ \\
\hline Asthma & $3(3)$ \\
\hline Chronic liver disease & $1(1)$ \\
\hline
\end{tabular}

Data are presented as medians (interquartile ranges) or as numbers (percentages). *Benign pulmonary diseases included pulmonary aspergillosis $(n=2)$, pulmonary tuberculosis $(n=3)$, non-specific inflammation $(n=6)$, and sarcoidosis $(n=1)$.

the combination tumor marker/CTC/ctDNA $(89.2 \%)$ assay was similar to that of the CTC/ctDNA assay $(86.5 \% ; p=0.250)$.

The CTC/ctDNA combination assay showed lower specificity $(16.7 \%)$ than that of tumor marker $(75.0 \%$; $p=0.048$ ) alone. The positive predictive values of the CTC,
ctDNA, and combination of CTC/ctDNA assays were similar ( $p=0.374$ for ctDNA $v s$. $c$ DNA/CTC combination; $p=0.999$ for CTC vs. ctDNA/CTC combination). The negative predictive values of the CTC, ctDNA, and combination of CTC/ctDNA assays were similar ( $p=0.754$ for $\operatorname{ctDNA} v s$. ctDNA/CTC combination; $p=0.602$ for CTC $v s$. ctDNA/CTC combination). The false positive rate of the combination CTC/ctDNA assay $(83.3 \%)$ was greater than false positive rates of the ctDNA $(58.3 \% ; p=0.750)$, CTC $(58.3 \% ; p=0.750)$ or tumor marker $(25.0 \% ; p=0.048)$ assays alone. The false negative rate was lower in combination of CTC/ctDNA assay $(5.1 \%)$ than false negative rates of the ctDNA $(27.3 \%$; $p<0.001)$ or CTC $(34.3 \% ; p<0.001)$ assays alone.

Subgroup analysis of diagnostic sensitivity of assays. Diagnostic sensitivity was analyzed by tumor stage and histopathology type (Table IV). In 34 patients with stage I and II NSCLC and limited disease of SCLC, the sensitivities of the CTC, ctDNA and combined CTC/ctDNA assays were $67.6 \%, 61.8 \%$, and $91.2 \%$, respectively ( $p=0.008$ for CTC $v s$. the combination assay; $p=0.002$ for ctDNA $v s$. the combination assay). In 36 patients with stage IV of NSCLC and extensive disease of SCLC, the sensitivity of the combination CTC/ctDNA assay was greater $(97.2 \%)$ than the sensitivities of the CTC $(69.4 \%$; $p=0.002)$ or ctDNA $(80.6 \% ; p=0.031)$ assays alone. In 62 patients with adenocarcinomas, the sensitivity of the combination CTC/ctDNA assay was greater (95.2\%) than the sensitivities of the CTC $(64.5 \% ; p<0.001)$ or ctDNA $(70.9 \%$; $p<0.001$ ) assays alone. In 24 patients with squamous cell carcinomas, the sensitivity of the combination CTC/ctDNA assay $(95.8 \%)$ was similar to that of ctDNA assay $(75.0 \%$; $p=0.126)$ but greater than that of CTC assay $(66.7 \% ; p=0.032)$.

CTCs. The results of the CTC assay are summarized in Table $\mathrm{V}$. The median CTC count in $10 \mathrm{ml}$ blood was 3 (IQR=1-5); CTC numbers $\geq 2$ (a positive finding) were detected in 72 patients (65 with lung cancer and 7 with benign pulmonary disease). The total CTC counts did not differ among stages $(p=0.991)$ or histopathology types $(p=0.899)$.

Single-nucleotide variations of ctDNA. Of the 111 patients who underwent liquid biopsy, $9(8 \%)$ lung cancer patients failed to obtain the result of ctDNA analysis; these were regarded as false negatives for analysis purposes. Of the 102 patients for whom ctDNA data were available, $79(77 \%)$ exhibited at least one alteration; the numbers of detected SNVs per gene are listed in Table VI. The median number of detected SNVs was 2 (IQR, 1-3); the most frequently detected SNV was TP53 (total count 103), followed by CDKN2A (total count 11), EGFR (total count 8) and PIK3CA (total count 8). Of the 36 patients with EGFR mutations detected in lung cancer tissue, the ctDNA assay detected EGFR mutation in blood sample of 8 (22\%) patients. 
Table III. Diagnostic performance of circulating tumor cells (CTC), circulating tumor DNA (ctDNA), and tumor marker assays for detection of lung cancer $(n=111)$.

\begin{tabular}{|c|c|c|c|c|c|c|c|c|c|c|}
\hline & CEA & $\begin{array}{c}\text { CYFRA } \\
21-1\end{array}$ & NSE & $\begin{array}{l}\text { Tumor } \\
\text { marker* }\end{array}$ & CTC & ctDNA & $\begin{array}{l}\text { Tumor } \\
\text { marker } \\
+ \text { CTC }\end{array}$ & $\begin{array}{l}\text { Tumor } \\
\text { marker } \\
+ \text { ctDNA }\end{array}$ & $\begin{array}{c}\text { CTC } \\
+c t D N A\end{array}$ & $\begin{array}{c}\text { Tumor } \\
\text { marker } \\
+\mathrm{CTC}+\mathrm{ctDNA}\end{array}$ \\
\hline Test positive, $\mathrm{n}$ & 29 & 42 & 43 & 69 & 72 & 79 & 98 & 96 & 104 & 107 \\
\hline Test negative, $\mathrm{n}$ & 82 & 69 & 68 & 42 & 39 & 32 & 13 & 15 & 7 & 4 \\
\hline $\begin{array}{l}\text { Sensitivity, \% } \\
(95 \% \text { CI })\end{array}$ & $\begin{array}{c}29.0 \\
(19.4-37.2)\end{array}$ & $\begin{array}{c}42.4 \\
(32.7-52.2)\end{array}$ & $\begin{array}{c}40.4 \\
(30.7-50.1)\end{array}$ & $\begin{array}{c}66.7 \\
(57.4-75.9)\end{array}$ & $\begin{array}{c}65.7 \\
(56.3-75.0)\end{array}$ & $\begin{array}{c}72.7 \\
(64.0-81.5)\end{array}$ & $\begin{array}{c}89.9 \\
(84.0-95.8)\end{array}$ & $\begin{array}{c}88.9 \\
(82.7-95.1)\end{array}$ & $\begin{array}{c}95.0 \\
(90.6-99.3)\end{array}$ & $\begin{array}{c}98.0 \\
(95.2-100.0)\end{array}$ \\
\hline $\begin{array}{l}\text { Accuracy, \% } \\
(95 \% \mathrm{CI})\end{array}$ & $\begin{array}{c}35.1 \\
(26.3-44.0)\end{array}$ & $\begin{array}{c}48.7 \\
(39.4-57.9)\end{array}$ & $\begin{array}{c}44.1 \\
(34.9-53.4)\end{array}$ & $\begin{array}{c}67.6 \\
(58.9-76.3)\end{array}$ & $\begin{array}{c}63.1 \\
(54.1-72.0)\end{array}$ & $\begin{array}{c}69.4 \\
(60.8-77.9)\end{array}$ & $\begin{array}{c}82.9 \\
(75.9-89.9)\end{array}$ & $\begin{array}{c}82.9 \\
(75.9-89.9)\end{array}$ & $\begin{array}{c}86.5 \\
(80.1-92.9)\end{array}$ & $\begin{array}{c}89.2 \\
(83.4-95.0)\end{array}$ \\
\hline $\begin{array}{l}\text { Specificity, \% } \\
(95 \% \text { CI) }\end{array}$ & $\begin{array}{c}90.9 \\
(76.0-100.0)\end{array}$ & $\begin{array}{l}100.0 \\
(\mathrm{~N} / \mathrm{A})\end{array}$ & $\begin{array}{c}75.0 \\
(50.5-99.5)\end{array}$ & $\begin{array}{c}75.0 \\
(50.5-99.5)\end{array}$ & $\begin{array}{c}41.7 \\
(13.8-69.6)\end{array}$ & $\begin{array}{c}41.7 \\
(13.8-69.6)\end{array}$ & $\begin{array}{c}25.0 \\
(0.5-49.5)\end{array}$ & $\begin{array}{c}33.3 \\
(6.7-60.0)\end{array}$ & $\begin{array}{c}16.7 \\
(0-37.8)\end{array}$ & $\begin{array}{c}16.7 \\
(0-37.8)\end{array}$ \\
\hline $\begin{array}{l}\text { Positive } \\
\text { predictive } \\
\text { value, } \% \\
(95 \% \mathrm{CI})\end{array}$ & $\begin{array}{c}96.7 \\
(89.9-100.0)\end{array}$ & $\begin{array}{l}100.0 \\
(\mathrm{~N} / \mathrm{A})\end{array}$ & $\begin{array}{c}93.0 \\
(85.4-100.0)\end{array}$ & $\begin{array}{c}95.7 \\
(90.8-100.0)\end{array}$ & $\begin{array}{c}90.3 \\
(83.4-97.1)\end{array}$ & $\begin{array}{c}91.1 \\
(84.9-97.4)\end{array}$ & $\begin{array}{c}90.8 \\
(85.1-96.5)\end{array}$ & $\begin{array}{c}91.7 \\
(86.1-97.2)\end{array}$ & $\begin{array}{c}90.4 \\
(84.7-96.1)\end{array}$ & $\begin{array}{c}90.7 \\
(85.1-96.2)\end{array}$ \\
\hline $\begin{array}{l}\text { Negative } \\
\text { predictive } \\
\text { value, } \% \\
(95 \% \mathrm{CI})\end{array}$ & $\begin{array}{c}12.4 \\
(6.0-20.8)\end{array}$ & $\begin{array}{c}17.4 \\
(8.5-26.3)\end{array}$ & $\begin{array}{c}13.2 \\
(5.2-21.3)\end{array}$ & $\begin{array}{c}21.4 \\
(9.0-33.8)\end{array}$ & $\begin{array}{c}12.8 \\
(2.3-23.3)\end{array}$ & $\begin{array}{c}15.6 \\
(3.0-28.2)\end{array}$ & $\begin{array}{c}23.1 \\
(0.2-46.0)\end{array}$ & $\begin{array}{c}26.7 \\
(4.3-49.1)\end{array}$ & $\begin{array}{c}28.6 \\
(0-62.0)\end{array}$ & $\begin{array}{c}50.0 \\
(1.0-99.0)\end{array}$ \\
\hline $\begin{array}{l}\text { False positive } \\
\text { rate, } \% \\
(95 \% \mathrm{CI})\end{array}$ & $\begin{array}{c}9.1 \\
(0-24.0)\end{array}$ & $\begin{array}{c}0 \\
(\mathrm{~N} / \mathrm{A})\end{array}$ & $\begin{array}{c}25.0 \\
(0.5-49.5)\end{array}$ & $\begin{array}{c}25.0 \\
(0.5-49.5)\end{array}$ & $\begin{array}{c}58.3 \\
(30.4-86.2)\end{array}$ & $\begin{array}{c}58.3 \\
(30.4-86.2)\end{array}$ & $\begin{array}{c}75.0 \\
(50.5-99.5)\end{array}$ & $\begin{array}{c}66.7 \\
(40.0-93.3)\end{array}$ & $\begin{array}{c}83.3 \\
(62.3-100.0)\end{array}$ & $\begin{array}{c}83.3 \\
(62.3-100.0)\end{array}$ \\
\hline $\begin{array}{l}\text { False negative } \\
\text { rate, } \%(95 \% \mathrm{CI}) \\
(95 \% \mathrm{CI})\end{array}$ & $\begin{array}{c}71.0 \\
(6.0-20.8)\end{array}$ & $\begin{array}{c}57.6 \\
(47.8-69.2)\end{array}$ & $\begin{array}{c}59.6 \\
(5.2-21.3)\end{array}$ & $\begin{array}{c}33.3 \\
(24.1-47.6)\end{array}$ & $\begin{array}{c}34.3 \\
(25.0-49.3)\end{array}$ & $\begin{array}{c}27.3 \\
(18.5-42.7)\end{array}$ & $\begin{array}{c}10.1 \\
(4.2-26.5)\end{array}$ & $\begin{array}{c}11.1 \\
(4.9-27.0)\end{array}$ & $\begin{array}{c}5.1 \\
(0.7-21.3)\end{array}$ & $\begin{array}{c}2.0 \\
(0-15.8)\end{array}$ \\
\hline
\end{tabular}

*Combination of CEA, CYFRA21-1, and NSE assays. CEA: Carcinoembryonic antigen; NSE: neuron-specific enolase; CI: confidence interval; N/A: not applicable.

\section{Discussion}

We prospectively evaluated liquid biopsy diagnostic performance in 111 patients with suspected lung cancer. The combination CTC/ctDNA assay sensitivity $(95.0 \%)$ was significantly greater than the sensitivities of the CTC $(65.7 \%)$, ctDNA $(72.7 \%)$ or tumor marker $(66.7 \%)$ assays alone. The specificity of the combination assay was lower $(16.7 \%)$ than the specificities of the CTC $(41.7 \%)$, ctDNA $(41.7 \%)$ or tumor marker $(75.0 \%)$ assays alone. In subgroup analysis, the sensitivity of the combined assay was greater than the sensitivities of the CTC or ctDNA assays alone, regardless of tumor stage or histopathology type. The median number of CTCs detected was 3 (IQR=1-5). The most frequently detected SNVs of ctDNA were TP53, CDKN2A, and EGFR.

Previous studies focused on differences between the CTC and ctDNA assays $(3,10)$. Because ctDNA is not directly derived from CTCs (19), neither assay was obviously preferable; thus, use of the two assays in a complementary manner has been suggested $(3,10,13,19,20)$. Herein, we assessed ctDNA and CTCs in the same blood sample; the combination assay achieved greater diagnostic sensitivity than either assay alone. To the best of our knowledge, this is the first study to demonstrate the synergism of the CTC and
ctDNA assays in terms of lung cancer diagnosis. Compared to the established conventional biomarker assay, the CTC assay achieved a greater diagnostic efficacy; we found that the combination CTC/ctDNA assay was more sensitive than an assay using three conventional tumor markers (21). Liquid biopsy is clinically relevant in terms of lung cancer screening $(7,13,22)$; the combination CTC/ctDNA assay may allow earlier cancer diagnosis and improved prognosis.

In terms of lung cancer diagnosis, the CTC assay sensitivities vary based on the technique used and the study population evaluated (3). We found that the assay sensitivity $(65 \%)$ was greater than that of previous reports (23-25). A combination of CTC/conventional tumor marker has been suggested to enhance diagnostic performance $(21,26)$, which is in consistence with our findings. On the other hand, although the associations between CTC numbers and stage/histological type (NSCLC vs. SCLC) were controversial in previous studies $(24,27,28)$, we found no differences in CTC numbers by stage or histological type. Various CTC detection methods have yielded different results and standardized platforms are required in the future $(9,13)$.

Earlier ctDNA assay studies achieved sensitivities of 36$58 \%$ in patients with stage I-IV NSCLC (29-31); our result was superior $(72.7 \%)$. The evaluated mutations have varied 
Table IV. Subgroup analysis of diagnostic sensitivities of circulating tumor cells (CTC), circulating tumor DNA (ctDNA), and tumor marker assays by tumor stage and histopathology type.

\begin{tabular}{|c|c|c|c|c|c|c|c|c|c|}
\hline CEA & CYFRA & $\begin{array}{l}\text { NSE } \\
21-1\end{array}$ & Tumor marker* & CTC & ctDNA & $\begin{array}{c}\text { Tumor } \\
\text { marker+CTC }\end{array}$ & $\begin{array}{c}\text { Tumor } \\
\text { marker } \\
+ \text { ctDNA }\end{array}$ & $\begin{array}{c}\text { CTC } \\
+ \text { ctDNA }\end{array}$ & $\begin{array}{c}\text { Tumor } \\
\text { marker } \\
+ \text { CTC+ctDNA }\end{array}$ \\
\hline
\end{tabular}

Stage I \& II and

$\mathrm{LD}(\mathrm{n}=34)$

Test positive, $\mathrm{n}$

Test negative, $\mathrm{n}$

Sensitivity, \%

5

29

14.7

4

$(95 \%$ CI $)$
Stage III $(\mathrm{n}=29)$

Test positive, $\mathrm{n}$

Test negative, $\mathrm{n}$.

Sensitivity, $\%$

(95\% CI)

(3.5-31.0)

30

$8 \quad 14$

11.7

26

20

23.5

41.2

23

11

21
13

27

7

79.4

$\begin{array}{ccc}27 & 31 & 32 \\ 7 & 3 & 2 \\ 79.4 & 91.2 & 94.1\end{array}$

(0.9-22.6)

(24.6-57.7) (51.9-83.4)

61.8

$(65.8-93.0)(81.6-100,0)(86.2-100.0)$

Stage IV \& ED

$(\mathrm{n}=36)$

Test positive, $\mathrm{n}$

Test negative, $\mathrm{n}$.

Sensitivity, \%

(95\% CI)

13

$8 \quad 19$

$19 \quad 17$

$44.8 \quad 27.6$

65.5

17
12

58.6

22

7

26

3

25
4

4

28

1

29

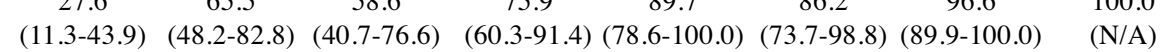

100.0

$(\mathrm{n}=62)$

Test positive, $\mathrm{n}$

Test negative, $\mathrm{n}$

Sensitivity, \%

(95\% CI)

$24 \quad 23$

$23 \quad 33$

$33 \quad 25$

13

3
917

25
11

29

29
7

66.7

63.9

91.7

69.4

80.6

36
0

100.0

36
0
100.0

35

$\begin{array}{cc}35 & 36 \\ 1 & 0\end{array}$

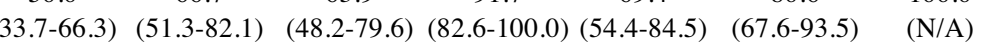

(N/A)

(91.9-100.0

100.0

(N/A)

Squamous cell

carcinoma $(n=24)$

Test positive,

Test negative, $\mathrm{n}$

Sensitivity, \%

(95\% CI)

$23 \quad 20$

$39-42$

$37.1 \quad 32.3$

19

43

37

25

59.7

40

22

64.5

44

18

70.9

55

88.7

52

$\begin{array}{ll}52 & 59\end{array}$

83.9

95.2

61

$\begin{array}{lllll}(19.2-42.1) & (47.5-71.9) & (52.6-76.4) & (59.7-82.3) & (80.8-96.6)\end{array}$

$(74.7-93.0)(89.8-100.0)(95.3-100.0)$

Small cell lung

cancer $(n=7)$

Test positive, $\mathrm{n}$

Test negative, $\mathrm{n}$

Sensitivity, \%

(95\% CI)

$4 \quad 13$

20

$13 \quad 11$

54.2

11

45.8

$\begin{array}{cc}18 & 16 \\ 6 & 8\end{array}$

75.0

66.7

$\begin{array}{cc}18 & 22 \\ 6 & 2\end{array}$

75.0

91.7

23

1

95.8

$\begin{array}{cc}23 & 23 \\ 1 & 1 \\ 95.8 & 95.8\end{array}$

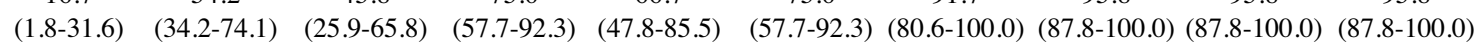

*Combination of CEA, CYFRA 21-1, and NSE assays. CEA: Carcinoembryonic antigen; NSE: neuron-specific enolase; LD: limited disease of small cell lung cancer; ED: extensive disease of small cell lung cancer; CI: confidence interval; N/A, not applicable.

Table V. Circulating tumor cell (CTC) counts by stage and histopathology type $(n=111)$.

\begin{tabular}{lcccc}
\hline & Total CTC counts & EpCAM $^{+} / \mathrm{CK}^{-}$CTCs & EpCAM $^{-} / \mathrm{CK}^{+} \mathrm{CTCs}$ & $\mathrm{EpCAM}^{+} / \mathrm{CK}^{+} \mathrm{CTCs}^{-}$ \\
\hline All patients (n=111) & $3(1-5)$ & $0(0-1)$ & $0(0-1)$ & $1(0-3)$ \\
Benign pulmonary disease (n=12) & $2.5(0-5)$ & $0(0-1)$ & $0(0-0.75)$ & $1(0-2.75)$ \\
Lung cancer (n=99) & $3(1-5)$ & $0(0-1)$ & $0(0-1)$ & $1(0-3)$ \\
Stage I+II and LD (n=34) & $2(1-4.25)$ & $0(0-1)$ & $0(0-1)$ & $1(0-3)$ \\
Stage III (n=29) & $3(1-5)$ & $0(0-1)$ & $0(0-1)$ & $2(0-3)$ \\
Stage IV and ED (n=36) & $3(1-4.75)$ & $0(0-2)$ & $0(0-1)$ & $1(0-2)$ \\
Adenocarcinoma (n=62) & $2(1-5)$ & $0(0-1)$ & $0(0-1)$ & $1(0-2.25)$ \\
Squamous cell carcinoma (n=24) & $3(1-5)$ & $0(0-1)$ & $0(0-1)$ & $1.5(0-3)$ \\
Small cell lung cancer $(\mathrm{n}=7)$ & $3(2-5)$ & $0(0-1)$ & $2(0-4)$ \\
\hline
\end{tabular}

Data are presented as medians (interquartile ranges). EpCAM: Epithelial cell adhesion molecule; CK: cytokeratin; LD: limited disease of small cell lung cancer; ED: extensive disease of small cell lung cancer. 
Table VI. Single nucleotide variations in circulating tumor DNA.

\begin{tabular}{|c|c|}
\hline Gene & Total \\
\hline ALK & 4 \\
\hline APC & 5 \\
\hline $\mathrm{AR}$ & 5 \\
\hline ARID1A & 4 \\
\hline BRAF & 2 \\
\hline BRCA1 & 5 \\
\hline BRCA2 & 5 \\
\hline CDKN2A & 11 \\
\hline CREBBP & 2 \\
\hline EGFR & 8 \\
\hline ERBB2 & 1 \\
\hline FGFR3 & 6 \\
\hline GNAQ & 1 \\
\hline JAK2 & 2 \\
\hline KIT & 8 \\
\hline KMT2D & 2 \\
\hline KRAS & 3 \\
\hline MAP2K1 & 1 \\
\hline MAP2K1 & 1 \\
\hline MED12 & 2 \\
\hline MET & 2 \\
\hline MTOR & 1 \\
\hline NFE2L2 & 2 \\
\hline NRAS & 1 \\
\hline PBRM1 & 5 \\
\hline PDGFRA & 4 \\
\hline PIK3CA & 8 \\
\hline PTEN & 9 \\
\hline RET & 2 \\
\hline ROS1 & 2 \\
\hline SMAD4 & 1 \\
\hline TERT & 3 \\
\hline TP53;WRAP53 & 2 \\
\hline TP53 & 103 \\
\hline
\end{tabular}

among studies; mutations in EGFR have been reported (29, 30) as well as mutations in KRAS, BRAF, HER2 and PIK3CA (31). The detection levels of EGFR mutations in both ctDNA and tissue were relatively low in a previous study $(35 \%$, $16 / 45)(30)$, as well as in our present work $(22 \%, 8 / 36)$. The discordance in terms of genomic alterations of matched tumor tissue and ctDNA in blood may suggest the possibility that tissue and ctDNA analyses are complementary $(32,33)$.

Our study had certain limitations. First, we enrolled a relatively small number of patients with benign pulmonary disease $(n=12)$; thus, assay specificity was not adequately evaluated. The diagnostic specificities of CTC and ctDNA were quite lower than the specificity of a conventional tumor marker combination. In previous reports, ctDNA false positives were attributed to age-related somatic mutations and clonal hematopoiesis $(34,35)$. In addition, CTCs could be detected in patients with benign disease and the CTC count could increase in larger blood volume $(36,37)$. These factors pose challenges for clinical application of liquid biopsy, such that more precise detection is required. Second, ctDNA data were missing for some patients suggesting that the technology for ctDNA isolation and genomic data analysis should be improved. Finally, the clinical utility of liquid biopsy in patients with multiple primary lung cancers and other tumors was not evaluated. We focused on liquid biopsy for the diagnosis of primary lung cancer; therefore, more research is needed regarding rare types of malignancy.

In conclusion, the combination CTC/ctDNA assay achieved primary lung cancer diagnostic sensitivity greater than those of the CTC or ctDNA assays alone. Therefore, it may be clinically useful for the early detection of lung cancer. Further studies with larger sample sizes are needed to confirm these findings.

\section{Conflicts of Interest}

Ji-ho Kim, Hyuk-Jung Kwon, Jin-Sik Bae, and Sunghoon Lee are employees and shareholders of EDGC Inc. Seong Keun Kim, Hye Seon Lee, Mi-Young Choi and Byung Hee Jeon are employees of Cytogen Inc. Seong Keun Kim, Hye Seon Lee and Byung Hee Jeon are shareholders of Cytogen Inc.

\section{Authors' Contributions}

S.M.M.: Conceptualization, data curation, formal analysis, writingoriginal draft, methodology. J.-H.K.: Data curation, resources, methodology. S.K.K.: Data curation, resources, methodology. S.K.: Data curation, formal analysis. H.-J.K.: Data curation, resources, methodology. J.-S.B: Data curation, resources, methodology. S.L.: Data curation, resources, methodology. H.S.L: Data curation, resources, methodology. M.-Y.C.: Data curation, resources, methodology. B.H.J.: Data curation, resources, methodology. B.-H.J.: Resources, writing-review \& editing. K.L.: Resources, writing-review \& editing. H.K.K.: Resources, writing-review \& editing. J.K.: Resources, writing-review \& editing. S.-W.U.: Conceptualization, resources, data curation, formal analysis, writing- original draft, writing-review \& editing, methodology, supervision.

\section{Acknowledgements}

This study did not receive any specific grant from any funding agency in the public or not-for-profit sectors. This research was supported by the research fund from CytoGen Inc. (Seoul, Republic of Korea) and EDGC, Inc. (Incheon, Republic of Korea).

\section{References}

1 Cheng TY, Cramb SM, Baade PD, Youlden DR, Nwogu C and Reid ME: The international epidemiology of lung cancer: latest trends, disparities, and tumor characteristics. J Thorac Oncol 11(10): 16531671, 2016. PMID: 27364315. DOI: 10.1016/j.jtho.2016.05.021

2 Siegel RL, Miller KD and Jemal A: Cancer statistics, 2016. CA Cancer J Clin 66(1): 7-30, 2016. PMID: 26742998. DOI: $10.3322 /$ caac. 21332 
3 Calabuig-Farinas S, Jantus-Lewintre E, Herreros-Pomares A and Camps C: Circulating tumor cells versus circulating tumor DNA in lung cancer-which one will win? Transl Lung Cancer Res 5(5): 466-482, 2016. PMID: 27826528. DOI: 10.21037/tlcr.2016.10.02

$4 \mathrm{Lu}$ J and Han B: Liquid biopsy promotes non-small cell lung cancer precision therapy. Technol Cancer Res Treat 17: 1533033818801809, 2018. PMID: 30244652. DOI: 10.1177/1533033818801809

5 Siravegna G, Mussolin B, Venesio T, Marsoni S, Seoane J, Dive C, Papadopoulos N, Kopetz S, Corcoran RB, Siu LL and Bardelli A: How liquid biopsies can change clinical practice in oncology. Ann Oncol 30(10): 1580-1590, 2019. PMID: 31373349. DOI: 10.1093/annonc/mdz227

6 Esposito A, Criscitiello C, Locatelli M, Milano M and Curigliano G: Liquid biopsies for solid tumors: Understanding tumor heterogeneity and real time monitoring of early resistance to targeted therapies. Pharmacol Ther 157: 120-124, 2016. PMID: 26615782. DOI: 10.1016/j.pharmthera.2015.11.007

7 Tanos R and Thierry AR: Clinical relevance of liquid biopsy for cancer screening. Transl Cancer Res 7: S105-129, 2018. DOI: 10.21037/tcr.2018.01.31

8 Mayo-de-Las-Casas C, Garzon Ibanez M, Jordana-Ariza N, Garcia-Pelaez B, Balada-Bel A, Villatoro S, Malapelle U, Karachaliou N, Troncone G, Rosell R and Molina-Vila MA: An update on liquid biopsy analysis for diagnostic and monitoring applications in non-small cell lung cancer. Expert Rev Mol Diagn 18(1): 35-45, 2018. PMID: 29172773. DOI: 10.1080/14737159.2018.1407243

9 Santarpia M, Liguori A, D'Aveni A, Karachaliou N, GonzalezCao M, Daffina MG, Lazzari C, Altavilla G and Rosell R: Liquid biopsy for lung cancer early detection. J Thorac Dis 10(Suppl 7): S882-S897, 2018. PMID: 29780635. DOI: $10.21037 /$ jtd .2018 .03 .81

10 Kidess E and Jeffrey SS: Circulating tumor cells versus tumorderived cell-free DNA: rivals or partners in cancer care in the era of single-cell analysis? Genome Med 5(8): 70, 2013. PMID: 23953663. DOI: $10.1186 / \mathrm{gm} 474$

11 Lim M, Kim CJ, Sunkara V, Kim MH and Cho YK: Liquid biopsy in lung cancer: clinical applications of circulating biomarkers (CTCs and ctDNA). Micromachines (Basel) 9(3): 100, 2018. PMID: 30424034. DOI: 10.3390/mi9030100

12 Schwarzenbach H, Hoon DS and Pantel K: Cell-free nucleic acids as biomarkers in cancer patients. Nat Rev Cancer 11(6): 426-437, 2011. PMID: 21562580. DOI: 10.1038/nrc3066

13 Castro-Giner F, Gkountela S, Donato C, Alborelli I, Quagliata L, $\mathrm{Ng}$ CKY, Piscuoglio $\mathrm{S}$ and Aceto $\mathrm{N}$ : Cancer diagnosis using a liquid biopsy: challenges and expectations. Diagnostics (Basel) 8(2): 31 , 2018. PMID: 29747380. DOI: 10.3390/diagnostics8020031

14 Choi SY, Lim B, Kyung YS, Kim Y, Kim BM, Jeon BH, Park JC, Sohn YW, Lee JH, Uh JH, Jang S and Kim CS: Circulating tumor cell counts in patients with localized prostate cancer including those under active surveillance. In Vivo 33(5): 16151620, 2019. PMID: 31471413. DOI: 10.21873/invivo.11645

15 Chen W, Liu Q, Tan SY and Jiang YH: Association between carcinoembryonic antigen, carbohydrate antigen 19-9 and body mass index in colorectal cancer patients. Mol Clin Oncol 1(5): 879-886, 2013. PMID: 24649265. DOI: 10.3892/mco.2013.158

16 Park SH, Ku KB, Chung HY and Yu W: Prognostic significance of serum and tissue carcinoembryonic antigen in patients with gastric adenocarcinomas. Cancer Res Treat 40(1): 16-21, 2008. PMID: 19688060. DOI: 10.4143/crt.2008.40.1.16
17 Li X, Lu J, Ren H, Chen T, Gao L, Di L, Song Z, Zhang Y, Yang T, Thakur A, Zhou SF, Yin Y and Chen M: Combining multiple serum biomarkers in tumor diagnosis: A clinical assessment. Mol Clin Oncol 1(1): 153-160, 2013. PMID: 24649139. DOI: $10.3892 / \mathrm{mco} .2012 .23$

18 Esscher T, Steinholtz L, Bergh J, Nou E, Nilsson K and Pahlman S: Neurone specific enolase: a useful diagnostic serum marker for small cell carcinoma of the lung. Thorax 40(2): 85-90, 1985. PMID: 2983452. DOI: $10.1136 /$ thx.40.2.85

19 Bettegowda C, Sausen M, Leary RJ, Kinde I, Wang Y, Agrawal N, Bartlett BR, Wang H, Luber B, Alani RM, Antonarakis ES, Azad NS, Bardelli A, Brem H, Cameron JL, Lee CC, Fecher LA, Gallia GL, Gibbs P, Le D, Giuntoli RL, Goggins M, Hogarty MD, Holdhoff M, Hong SM, Jiao Y, Juhl HH, Kim JJ, Siravegna G, Laheru DA, Lauricella C, Lim M, Lipson EJ, Marie SK, Netto GJ, Oliner KS, Olivi A, Olsson L, Riggins GJ, SartoreBianchi A, Schmidt K, Shih 1 M, Oba-Shinjo SM, Siena S, Theodorescu D, Tie J, Harkins TT, Veronese S, Wang TL, Weingart JD, Wolfgang CL, Wood LD, Xing D, Hruban RH, Wu J, Allen PJ, Schmidt CM, Choti MA, Velculescu VE, Kinzler KW, Vogelstein B, Papadopoulos N and Diaz LA, Jr.: Detection of circulating tumor DNA in early- and late-stage human malignancies. Sci Transl Med 6(224): 224ra224, 2014. PMID: 24553385. DOI: 10.1126/scitranslmed .3007094

20 Ignatiadis $M$ and Dawson SJ: Circulating tumor cells and circulating tumor DNA for precision medicine: dream or reality? Ann Oncol 25(12): 2304-2313, 2014. PMID: 25336116. DOI: 10.1093/annonc/mdu480

21 Wang L, Wu C, Qiao L, Yu W, Guo Q, Zhao M, Yang G, Zhao $\mathrm{H}$ and Lou J: Clinical significance of folate receptor-positive circulating tumor cells detected by ligand-targeted polymerase chain reaction in lung cancer. J Cancer 8(1): 104-110, 2017. PMID: 28123603. DOI: 10.7150/jca.16856

22 Johann DJ, Jr., Steliga M, Shin IJ, Yoon D, Arnaoutakis K, Hutchins L, Liu M, Liem J, Walker K, Pereira A, Yang M, Jeffus $\mathrm{SK}$, Peterson $\mathrm{E}$ and $\mathrm{Xu} \mathrm{J}$ : Liquid biopsy and its role in an advanced clinical trial for lung cancer. Exp Biol Med (Maywood) 243(3): 262-271, 2018. PMID: 29405770. DOI: $10.1177 / 1535370217750087$

23 Carlsson A, Nair VS, Luttgen MS, Keu KV, Horng G, Vasanawala M, Kolatkar A, Jamali M, Iagaru AH, Kuschner W, Loo BW, Jr., Shrager JB, Bethel K, Hoh CK, Bazhenova L, Nieva J, Kuhn $\mathrm{P}$ and Gambhir SS: Circulating tumor microemboli diagnostics for patients with non-small-cell lung cancer. J Thorac Oncol 9(8): 1111-1119, 2014. PMID: 25157764. DOI: $10.1097 / \mathrm{JTO} .0000000000000235$

24 Hofman V, Long E, Ilie M, Bonnetaud C, Vignaud JM, Flejou JF, Lantuejoul S, Piaton E, Mourad N, Butori C, Selva E, Marquette $\mathrm{CH}$, Poudenx M, Sibon S, Kelhef S, Venissac N, Jais JP, Mouroux J, Molina TJ, Vielh P and Hofman P: Morphological analysis of circulating tumour cells in patients undergoing surgery for nonsmall cell lung carcinoma using the isolation by size of epithelial tumour cell (ISET) method. Cytopathology 23(1): 30-38, 2012. PMID: 21210876. DOI: 10.1111/j.1365-2303.2010.00835.x

25 Hofman V, Bonnetaud C, Ilie MI, Vielh P, Vignaud JM, Flejou JF, Lantuejoul S, Piaton E, Mourad N, Butori C, Selva E, Poudenx M, Sibon S, Kelhef S, Venissac N, Jais JP, Mouroux J, Molina TJ and Hofman P: Preoperative circulating tumor cell detection using the isolation by size of epithelial tumor cell method for patients with lung cancer is a new prognostic 
biomarker. Clin Cancer Res 17(4): 827-835, 2011. PMID 21098695. DOI: 10.1158/1078-0432.CCR-10-0445

26 Chen X, Wang X, He H, Liu Z, Hu JF and Li W: Combination of circulating tumor cells with serum carcinoembryonic antigen enhances clinical prediction of non-small cell lung cancer. PLoS One 10(5): e0126276, 2015. PMID: 25996878. DOI: 10.1371/journal.pone. 0126276

27 Wendel M, Bazhenova L, Boshuizen R, Kolatkar A, Honnatti M, Cho EH, Marrinucci D, Sandhu A, Perricone A, Thistlethwaite P, Bethel K, Nieva J, Heuvel M and Kuhn P: Fluid biopsy for circulating tumor cell identification in patients with early-and late-stage non-small cell lung cancer: a glimpse into lung cancer biology. Phys Biol 9(1): 016005, 2012. PMID: 22307026. DOI: 10.1088/1478-3967/9/1/016005

28 Tanaka F, Yoneda K, Kondo N, Hashimoto M, Takuwa T, Matsumoto S, Okumura Y, Rahman S, Tsubota N, Tsujimura T, Kuribayashi K, Fukuoka K, Nakano $\mathrm{T}$ and Hasegawa $\mathrm{S}$ : Circulating tumor cell as a diagnostic marker in primary lung cancer. Clin Cancer Res 15(22): 6980-6986, 2009. PMID: 19887487. DOI: 10.1158/1078-0432.CCR-09-1095

29 Rosell R, Moran T, Queralt C, Porta R, Cardenal F, Camps C, Majem M, Lopez-Vivanco G, Isla D, Provencio M, Insa A, Massuti B, Gonzalez-Larriba JL, Paz-Ares L, Bover I, GarciaCampelo R, Moreno MA, Catot S, Rolfo C, Reguart N, Palmero R, Sanchez JM, Bastus R, Mayo C, Bertran-Alamillo J, Molina MA, Sanchez JJ, Taron M and Spanish Lung Cancer G: Screening for epidermal growth factor receptor mutations in lung cancer. N Engl J Med 361(10): 958-967, 2009. PMID: 19692684. DOI: $10.1056 /$ NEJMoa0904554

30 Zhao X, Han RB, Zhao J, Wang J, Yang F, Zhong W, Zhang L, Li LY and Wang MZ: Comparison of epidermal growth factor receptor mutation statuses in tissue and plasma in stage I-IV non-small cell lung cancer patients. Respiration 85(2): 119-125, 2013. PMID: 22797485. DOI: 10.1159/000338790

31 Couraud S, Vaca-Paniagua F, Villar S, Oliver J, Schuster T, Blanche H, Girard N, Tredaniel J, Guilleminault L, Gervais R, Prim N, Vincent M, Margery J, Larive S, Foucher P, Duvert B, Vallee M, Le Calvez-Kelm F, McKay J, Missy P, Morin F, Zalcman G, Olivier M, Souquet PJ and Bio CI-i: Noninvasive diagnosis of actionable mutations by deep sequencing of circulating free DNA in lung cancer from never-smokers: a proof-of-concept study from BioCAST/IFCT-1002. Clin Cancer Res 20(17): 4613-4624, 2014. PMID: 25013125. DOI: 10.1158/1078-0432.CCR-13-3063
32 Chang YS, Fang HY, Hung YC, Ke TW, Chang CM, Liu TY, Chen YC, Chao DS, Huang HY and Chang JG: Correlation of genomic alterations between tumor tissue and circulating tumor DNA by next-generation sequencing. J Cancer Res Clin Oncol 144(11): 2167-2175, 2018. PMID: 30203147. DOI: 10.1007/s00432-018-2747-9

33 Guo Q, Wang J, Xiao J, Wang L, Hu X, Yu W, Song G, Lou J and Chen J: Heterogeneous mutation pattern in tumor tissue and circulating tumor DNA warrants parallel NGS panel testing. Mol Cancer 17(1): 131, 2018. PMID: 30153823. DOI: 10.1186/s12943018-0875-0

34 Milholland B, Auton A, Suh Y and Vijg J: Age-related somatic mutations in the cancer genome. Oncotarget 6(28): 2462724635, 2015. PMID: 26384365. DOI: 10.18632/oncotarget.5685

$35 \mathrm{Hu}$ Y, Ulrich BC, Supplee J, Kuang Y, Lizotte PH, Feeney NB, Guibert NM, Awad MM, Wong KK, Janne PA, Paweletz CP and Oxnard GR: False-positive plasma genotyping due to clonal hematopoiesis. Clin Cancer Res 24(18): 4437-4443, 2018. PMID: 29567812. DOI: 10.1158/1078-0432.CCR-18-0143

36 Ding C, Zhou X, Xu C, Chen J, Ju S, Chen T, Liang Z, Cui Z, $\mathrm{Li} \mathrm{C}$ and Zhao $\mathrm{J}$ : Circulating tumor cell levels and carcinoembryonic antigen: An improved diagnostic method for lung adenocarcinoma. Thorac Cancer 9(11): 1413-1420, 2018. PMID: 30178907. DOI: 10.1111/1759-7714.12851

37 Lalmahomed ZS, Kraan J, Gratama JW, Mostert B, Sleijfer S and Verhoef $\mathrm{C}$ : Circulating tumor cells and sample size: the more, the better. J Clin Oncol 28(17): e288-289; author reply e290, 2010. PMID: 20439640. DOI: 10.1200/JCO.2010.28.2764
Received March 29, 2020

Revised May 5, 2020

Accepted May 11, 2020 